\title{
Bogusław Bakuła's No Dependencies, the History and Analysis of the Polish Independent Literary and Cultural Movement Between 1976 and 1989
}

\author{
lgnác Nagy
}

independent researcher; nagyignac@yahoo.com

\section{The Topic}

Bogusław Bakuła’s current work Nie zależności, which could be translated into English as No Dependencies: the history of independent literature and culture in Poland between 1976-1989, studying trends and phenomena in literature, journalism and the humanities in independent circulation in Poland despite the widespread censorship applied by the communist state. It focuses on the reality contained in the works of independent authors, and shows the contemporary attitude towards history in essays and other literary works. The book presents the oppositional self reflection to truth, identity and creative processes. The author also describes the phenomenon of spoken magazines in the context of independent culture, comparing the Polish to the Czechoslovak and Ukrainian samizdat.

\section{No dependencies; or the history of Polish independent literature as presented by professor Bogusław Bakuła}

Born in Warsaw, Bogusław Bakuła graduated from the Adam Mickiewicz University in Poznań, where he is currently heading the Department of Comparative Literary and Cultural Studies at the Institute of Polish Philology.

His research interests include Polish and Slavic Philology, comparative research in literature and culture, intercultural communication, research on Central Europe as a cultural area, post-communist transformation, Ukrainian, Belarusian and Russian philology, Central European literature and anti-communist opposition, the history of and culture of samizdat and independent literature.

The title of the current book No Dependencies merges from a research project carried out in 2009 at Forschungsstelle Osteuropa at the University of Bremen. A truncated version was first published under the German title. ${ }^{1}$

1 Bakuła, "Eine paralelle Welt." 
Bakuła has a strong personal attachment to the book's subject matter due to his personal involvement in the independent literary movement. From the introduction of martial law to the collapse of the communist regime the author was actively engaged in the underground publishing and literary life of the Polish opposition. It follows naturally from his own experience that in his research career he has dedicated special attention to the Polish samizdat underground literature

This book gives precise analytic insight into Polish independent literature, like severalof it's forebearers in the nineties and later. Many scholars had tried to summarize and describe Polish independent culture; with Beata Dorosz among them, who claimed as early as 1995 in her paper „Poza cenzura” na cenzoruwanym (Beyond Censorship On The Censored) that Polish independent literature should receive more scholarly attention and acknowledgement.

Another remarkable example of esearch on topic is the 2016 book entitled Drugi obieg w PRL na tle samizdatu w państwach bloku sowieckiego po 1956 roku (The Second Circulation in The Polish People's Republic in face of Samizdat in the Soviet Block Countries after 1956), edited by Przemysław Gasztold-Seń, Natalia Jarska and Jan Olaszek. This study, released by the Institue of National Remembrance, also reflects on the phenomenon of independent culture in Poland, offering diverse interpretations, evaluations and historical perceptions.

Bakuła's structure, and analytical logic resembles the aforementioned book. However his effort at classification and analysis is deeper and more detailed, handling and describing the topic in a more critical manner, while providing an enjoyable and highly informative source of knowledge for every reader interested in this thriving cultural phenomena.

An important finding of Bakuła's work is that independent literature was nothing new to Polish culture, because it had existed during the Partition of Poland, and was revived during the times of the Nazi and Soviet occupation. He shows that the Polish nation has always been supported by this kind of underground and independent culture, which was outside the scope of censorship. According to Bakuła the creation of an independent culture and literature is something uniquely Polish, helping to maintain the spirit of the Poles and the survival of their culture in their historical struggles.

Bakuła's work consists of ten sections: the first part is titled The Social realism in the independent literature describing the cultural life under the pressure of the official social realist requirements. The second section is titled History and remembrance, the third's title is Towards Others, the fourth is Autoreflection and discussions about consciousness, Bakuła gave the title Oral Literary Journals and Their Role in Independent Culture in the Eighties, the next section is called Polish, Czechoslovakian and Ukrainian Independent Literature between the sixties and 
eighties. The sixth part's title is Reflections on Independent Literature and Culture 1976-2016, the seventh bears the title Unbearable Lightness of Turning Years. The later sections are about literary and scholarly sources: the eight section lists the independent literary texts, in the ninth section we may find a bibliography of reserches on independent literature between 1976-2016, and the tenth section contains Index of People related to the independent literary phenomena.

Cultural life produced a unique form of culture as a result of which by the eighties, the underground or independent culture had reached unprecedented strength; and the cultural output of independent authors surpassed the official cultural life in quality, quantity and popularity. The author points out that unlike in other communist states the Catholic Church played an enormous role in sustaining national culture and the awareness of resistance. He aurgues that, socialist realism meant a corrupted form of arts in the name of Stalinist and later communist doctrine, therefore the aestethics of socialist realism could be interpreted as an open attack against Polish culture.

Bakuła also examines the term sanmizdat, and describes its history in Polish culture. In his interpretation, the term is not welcomed in Polish terminology, since it implies that the phenomenon did not exist before Nikolay Glazkov. Bakuła suggests instead the Polish term bibuła literally meaning a piece of cheap papaer, because independent literary tradition goes much further back into Poland's turbulent history. He explains that the need for independent literature is rooted in Polish society, and was always a form of resistance against oppressors. However I would add, that the Polish tradition is not uniquely Polish, because the Lithuanians had similar struggles during the press ban between 1865 and 1904, and with the active support of their clergy the Lithuanians maintained an effective illegal book printing and smuggling network in the face of tsarist repression.

The next aspect Bakuła examines is the documentation of the crimes committed by the totalitarian regimes and invaders of Poland. The occupants' acts were typically not described in the official cultural agenda or their factuality was changed. This resulted in independent literature being the only truthful source for the Polish readers. Thus, it was the works of independent authors that revealed and described in detail the crimes committed against the people.

Bakuła analyses how official culture and its propaganda manipulated reality stating that independent culture was the real witness of reality, the source of truth in a world of lies. The author compares uncensored literature to an autopsy that gives an accurate cross section of communist society and its realities.

In the first section Bakuła also investigates the language and the state of mind represented by social realism. He highlights that the language and style of independent Polish literature was a counterbalance against socialist realist efforts at 
depriving the language of its former estethics and semantics. Bakuła, argues that irony and jokes were the tools for expressing hopelessness in the reality of the communist regime, which was certainly not a solely Polish phenomenon.

The main guidelines in the second section are history and remembrance. The author lists the key milestones of Polish history and culture, and examines their effect on Polish national consciousness and development under the communist regime. Bakuła gives us a magnificent example of how the communist authorities tried to hijack Polish culture, through celebrating the fiftieth anniversary in 1967 of the Bolshevik Revolution with Mickiewicz's Dziady (Forefathers' Eve), an attempt that turned out to be self destructive for authorities.

Falsification attempts characterized not only literature, but also the official interpretation of Polish history, because the official historical agenda relied on falsified facts and counterfeit explanations. Bakuła explainns, that independent authors reacted to such lies in the form of essays. The essay was a perfect tool for processing historical facts concealed by the regime. He notes that there was another factor that added to the failure of historical falsification: the official agenda about he PolishRussian and later Polish-Soviet relations, which the Polish people rejected.

The works of Miłosz, Wat, Mackiewicz, Gombrowicz, Lechon and many other men of letters contributed to independent Polish literature and the survival of Polish culture and historical remembrance, and without the input of independent artists, musicians and authors Polish history and culture would have been subject to irreversible transformation.

The third section is called Towards Others. It is about the relations of Poles and their neighbors as it presented in independent literature. Bakuła has already described in the previous chapter, that the official agenda was far from the Pole's real historical perception of attitude towards others. For example emigrant authors and writers enjoyed increased prominence in Polish society, as they represented their contact to the outside non-communist world and also the source of truth.

The next important topics in the section are the two aspects of Polish national consciousness, which aspects were mutually conflicting with each other, as described by Jan Józef Lipski. These two aspects were xenophobic nationalism and megalomania, the exaggerated and emotionally defined characteristics of Polishness. The two ideas resulted in the fact that there were no mutual and fruitful dialogues neither between the Poles and their neighbors nor their Western counterparts. However during the existance of communist Poland the Poles' aim was always to join the West.

A recurring topic in the section as well as in the entire book is Polish-Russian and the Polish-Soviet relations, stranded by occupation, aggression and oppression, however the Poles thought that apart from their culture, the Soviet regime had also stolen the history of Russians, and by this logic the Polish and Russian nations were 
seen having shared some similarities in their fate. Bakuła explains this feeling with the popularity of samizdat texts of prominent Soviet writers like Anna Akhmatova, Isaak Babel, Osip Madelstam and Varlam Shalamov. The tropes, topics and realities emerging in Soviet samizdats reflected to the Polish and in a wider sense the Eastern European reality.

As Russia and the Soviet Union were subjects of comparison and fear, the Russian trope is a significant returning motif in the works of independent Polish authors. Scholars like Tadeusz Konwicki named this phenomena the „Russian problem” or „Polish complex” in the Polish literature. In the eyes of many Polish authors Russia turned into the manifestation of evil, a destructive determined to abduct and enslave Polish history.

In contrast, Germany, another key protagonist for Poland in the twentieth century had a different status in independent literature. German war crimes were certainly addressed in many works, but the West German state managed to gain some sympathy with the Poles, which was a new layer in the relationship of the two nations. As the West German state and society were sympatethic with the Polish cause and anti-communist struggle, the German approach gave Poles some hope that even in the shadow of the Soviet Union the two nations could eventually settle their differences. Germany as a topic did not have a prominent role in independent Polish literature, because the West German state was not an obstacle in the way towards indepedent Polish state.

The section ends with the analysis of the role of bruLion and Czas Kultury, the two journals that turned away from the national-Catholic and historic perspective in Polish culture. The young authors gathered around these two media were more interested in contemporary Western cultural influences and, pacifism and their works were dominated by hope and for peaceful co-existence with tPoland's neighbors.

The fourth section is about the selfreflection and discussion cocerning national consciousness. Bakuła examines the sources of selfreflection and the patterns of discussion about Polish national consciousness. The Polish opposition had formulated its own concept of culture despite censorship and the totalitarian cultural concept. Bakuła lists some important approaches characteristic of the independent literary movement, such as skepticism, avantgarde and social parnassism. As the author summarizes the key questions of selfreflection, the main tasks of independent art, especially in literature were leading the discussion about Polishness; history and main principles of proper historical perception. The main argument of this section is that the principal form of independent culture in Poland was literature, and other forms of arts followed suit in developing opposition to the communist regime to influence national consciousness and culture. 
The book's fifth section reviews the role of independent literary journals in communist Poland. Journals like NaGłos and Struktura Trzecia played a pivotal role during the last years of the agonizing communist regime by openly demanding changes in society and the country's political system. These two journals were so called oral journals organized also as literary evenings and lectures and as such were not subjected to censorship. The gatherings of the oral journals were legal, but their content and aim were obviously illegal under communist laws. The oral journals had another important advantage according to Bakuła, namely that they brought together independent authors and their audiences, so that during such gatherinmgs they could openly and freely discuss the most important burning social questions.

The sixth section gives an insight to the literary movements of Poland's neighbors comparing them to the Polish movement, which was much greater in scale and managed to reach out to a wider public. Bakuła writes for instance, that the Hungarian and Czech independent literary movements were less powerful and widespread than the Polish. He summarizes that the Czech and Hungarian independent authors could be rather found among emigrés. Bakuła investigates parallels between the literary movements, pointing out regional tendencies and achievements of respective independent literary movements.

The last explicative section describes the reflection on independent literary movement up to the year 2016, taking note of the relevant research and scholars in the field together with their remarkable results. This part gives us a useful insight into the research as a whole, and specifies the repositories of sources, bibliographies and publishers of independent materials, thereby offering essential help to the scholars researching related topics. The section ends with the summary of the scholarly reflection on the independent literary movement after 1989 and tries to define some new and important tasks and challenges. Bakuła points out that the results of the regime change might be preserved if the nation doesnot forget the struggle that finally resulted in freedom of speech, election and culture.

As far as the book's shortcomings are concerned, the only point I could mention is that it tries to implement the traditional Polish point of view about history and culture in the research of this significant field as well, but the applied Polish perspective in the sixth and seventh sections Bakuła makes a leap forward by comparing the Polish independent literary movement to the other nations' similar efforts, putting the whole phenomena into a broader, Eastern European context.

The book's strentgth is its enormous volume of information carefully processed and organized by the author, making it an enjoyable yet informative and interesting text. The rich materials, and abundant resources support the author's effort to synthetize the main features of Polish independent literature. Bakuła's cultural investigation takes the reader on a journey into the anatomy of the Polish independent 
literary movement. He not only presents and analyses the data but provides examples that evoke the essence and significance of the movement. The book is an engrossing material not only for scholars but for anyone interested in the everyday life and culture of the Polish People's Republic.

Bakuła's work is also a reliable source of information for scholars and researchers trying to rediscover the Polish independent literary movement. The book could be used as a guide to this cultural phenomena, listing all the difficulties and beauties that a researchers could face during their work.

Another remarkable result of the author's work is that he puts the independent literary movement into a historical and literary context, demonstrating that it is a part of a centuries long tradition.

\section{Bibliography}

Bakuła, Bogusław. Eine parallele Welt. Beiträge zur unabhängigen Kultur in Polen 1976-1989. Bielefeld: Societas Pars Mundi, 2018. 